\title{
Eligibility for home oxygen programs and funding across Canada
}

\author{
Yves Lacasse MD MSc FRCP, Sarah Bernard MSc, François Maltais MD FRCP
}

Y Lacasse, S Bernard, F Maltais. Eligibility to home oxygen programs and funding across Canada. Can Respir J 2015;22(6):324-330.

BACKGROUND: In Canada, although medical insurance is generally universal, significant differences exist in the provision of home oxygen therapy across the country.

OBJECTIVE: To systematically compare the terms of reference for home oxygen across Canada, with a focus on the clinical inclusion criteria to the programs.

METHODS: The authors searched the terms of reference of the 10 Canadian provinces and three territories, focusing on general eligibility criteria for home oxygen (including blood gas criteria, and eligibility criteria for ambulatory and nocturnal oxygen), and compared the eligibility criteria to the widely accepted criteria of the Nocturnal Oxygen Therapy Trial (NOTT) trial, the clinical recommendations of the Canadian Thoracic Society and the results of Cochrane reviews.

RESULTS: The terms of reference for nine provinces were retrieved. All jurisdictions have similar criteria for long-term oxygen therapy, with slight differences in the thresholds of prescription and the clinical criteria defining 'pulmonary hypertension' or 'cor pulmonale'. The use of oxyhemoglobin saturation as a criterion for funding is inconsistent. All nine provinces fund nocturnal oxygen, all with different clinical criteria. Funding for portable oxygen widely varies across provinces, whether the ambulatory equipment is offered to patients on long-term oxygen therapy or to those who have isolated exercise-induced desaturation. The terms of reimbursement are very heterogeneous.

CONCLUSIONS: Heterogeneity exists in the criteria for eligibility to home oxygen programs and funding across Canada. Terms of prescription and reimbursement of oxygen are not necessarily supported by available evidence from the current literature in several Canadian jurisdictions.

Key Words: Chronic lung diseases; COPD; Eligibility; Funding; Home oxygen programs; Oxygen therapy

Two landmark trials conducted $>30$ years ago provided scientific 1 evidence that, under very specific circumstances, long-term oxygen therapy (LTOT) may prolong life $(1,2)$. These two trials targeted patients with chronic obstructive pulmonary disease (COPD) and severe daytime hypoxemia documented using direct arterial blood gas measurement. A total of 290 patients were randomly assigned: 87 in the British trial (1) and 203 in the American trial (2). Both studies focused on life prolongation rather than quality of life, and cost effectiveness was not an issue at the time. Thereafter, oxygen therapy became standard of care in COPD, and confirmatory trials would now be considered unethical by many clinicians and scientists. New indications of oxygen therapy in COPD (such as nocturnal oxygen therapy in patients with isolated nocturnal oxygen desaturation, or ambulatory oxygen to correct exercise-induced desaturation) have since emerged. Oxygen therapy has also gained widespread acceptance by official organizations for the management of many other chronic cardiorespiratory conditions complicated by severe hypoxemia, even if proof of efficacy is lacking (3-5). In addition, oxygen is often prescribed to alleviate dyspnea in patients receiving palliative care.

Home oxygen therapy is expensive. For instance, in the Canadian cohort of the Confronting COPD Survey $(n=401$; mean age 63 years; $51 \%$ female; 35 [8.7\%] on LTOT), oxygen therapy accounted for $17 \%$ of the entire annual direct costs of COPD care (6). Unfortunately,

\section{L'admissibilité aux programmes d'oxygénothérapie à domicile et à leur financement au Canada}

HISTORIQUE : Même si l'assurance-maladie est généralement universelle au Canada, on constate d'importantes différences dans la prestation de l'oxygénothérapie à domicile en fonction des régions.

OBJECTIF : Comparer systématiquement les modalités liées à l'oxygénothérapie à domicile dans les diverses régions du Canada, en s'attardant sur les critères d'inclusion clinique.

MÉTHODOLOGIE : Les auteurs ont cherché les modalités des dix provinces et des trois territoires du Canada et se sont attardés aux critères généraux d'admissibilité à l'oxygénothérapie à domicile (y compris les critères de gaz sanguins et les critères d'admissibilité à l'oxygénothérapie ambulatoire et nocturne). Ils ont comparé les critères d'admissibilité aux critères largement acceptés de l'essai sur l'oxygénothérapie nocturne (NOTT), les recommandations cliniques de la Société canadienne de thoracologie et les résultats des analyses Cochrane.

RÉSULTATS : Les chercheurs ont extrait les modalités de neuf provinces. Toutes possèdent des critères similaires pour l'oxygénothérapie à long terme, malgré de légères différences quant aux seuils d'ordonnance et aux critères cliniques pour définir « l'hypertension pulmonaire » ou le « cœur pulmonaire ». La saturation en oxyhémoglobine n'est pas toujours un critère de financement. Les neuf provinces financent l'oxygénothérapie nocturne, toutes selon des critères cliniques différents. Le financement des réservoirs d'oxygène portatifs varie considérablement selon les provinces, qu'il soit offert aux patients sous oxygénothérapie à long terme ou à ceux qui souffrent de désaturation isolée causée par l'exercice. Les modalités de remboursement sont très hétérogènes.

CONCLUSIONS : Les critères d'admissibilité à l'oxygénothérapie à domicile et à son financement sont hétérogènes au Canada. D'après les données tirées des publications à jour de plusieurs régions sociosanitaires du Canada, les modalités de prescription et le remboursement de l'oxygène ne sont pas toujours offerts.

inappropriate prescriptions of home oxygen are not unusual (7). In this regard, the American Thoracic Society and the American College of Chest Physicians identified the prescription of supplemental home oxygen following hospitalization for an acute illness as one of the top five tests or interventions that are commonly and incorrectly used at great expense in adult pulmonary medicine (8).

In Canada, provinces and territories are responsible for delivering health care services, guided by the provisions of the Canada Health Act. Although medical insurance is generally universal, we realized, in our planning of a national trial of nocturnal oxygen therapy in COPD (the INOX trial; ClinicalTrials.gov NCT01044628), that significant differences exist in the provision of home oxygen therapy across the country. These differences are created and maintained within home oxygen programs by province-specific terms of reference defining and governing eligibility to equipment, allied services and reimbursement.

From this observation, we undertook the present study with the primary objective of systematically comparing the terms of reference to oxygen therapy across Canada, with a focus on the clinical inclusion criteria to the programs. Our secondary objective was to confront these eligibility criteria to the current national COPD clinical practice guidelines and to the best evidence from the literature. We also sought to describe the terms of reimbursement across jurisdictions.

Centre de recherche, Institut universitaire de cardiologie et de pneumologie de Québec, Université Laval, Québec, Québec

Correspondence Dr Yves Lacasse, Centre de Pneumologie, Institut Universitaire de cardiologie et de pneumologie de Québec, 2725 Chemin

Ste-Foy, Québec, Québec G1V 4G5. Telephone 418-656-4747, fax 418-656-4762, e-mail yves.lacasse@med.ulaval.ca 


\section{METHODS}

Terms of reference: inclusion and retrieval

The authors consulted the websites of the ministries or divisions of health for the document reporting on the terms of reference to oxygen therapy of the 10 Canadian provinces and three territories. For validation purposes, whenever necessary, or when no document was available on the Internet, the provincial or territorial division responsible for home care programs was directly contacted. As a last resort, a respirologist involved in the care of patients with COPD was contacted to obtain information on the provision of home oxygen in his/her province. To be considered, the documents had to be officially endorsed by the provincial or federal governments. Prescription forms or clinical guides from private oxygen suppliers were, therefore, excluded.

\section{Data extraction}

From each document, two reviewers (YL and SB) extracted the following information: date of publication; who is accredited to prescribe oxygen; the eligible diagnoses (including COPD and other cardiorespiratory conditions); general eligibility criteria for home oxygen (including blood gas criteria, and eligibility criteria to ambulatory and nocturnal oxygen); eligibility for oxygen therapy in palliative care; whether current smokers are eligible to home oxygen; and the terms of reimbursement.

Comparison with the current Canadian recommendations and international literature

General eligibility criteria for LTOT in COPD were compared with the usual and widely accepted criteria of the Nocturnal Oxygen Therapy Trial (NOTT): in a period of clinical stability, partial pressure of oxygen in arterial blood $\left(\mathrm{PaO}_{2}\right) \leq 55 \mathrm{mmHg}$; or $\mathrm{PaO}_{2} \leq 59 \mathrm{mmHg}$ with clinical evidence of at least one of the following: peripheral edema (cor pulmonale); hematocrit $\geq 55 \%$; or right ventricular hypertrophy (P pulmonale on electrocardiogram: $3 \mathrm{~mm}$ in leads II, III, aVF) (2). The eligibility criteria for nocturnal and ambulatory oxygen were also correlated with the clinical recommendations put forward by the Canadian Thoracic Society (CTS) in its latest practice guidelines targeting COPD (9). Although this document was published by an official organization, it has no authority on the provision or reimbursement of oxygen in the country. For indications and conditions other than LTOT in COPD, the eligibility criteria for home oxygen programs were compared with the results of Cochrane reviews. In this comparison, investigation of the use of oxygen was limited to two clinical conditions that were selected a priori: interstitial lung diseases (10) and palliative care (11).

\section{Analysis}

The present study was descriptive only. Statistics were limited to proportions. No statistical comparisons were involved.

\section{Terms of reference (Table 1 )}

\section{RESULTS}

The terms of reference for nine of the 10 Canadian provinces were retrieved. There is no home oxygen program in Newfoundland, Yukon, the Northwest Territories (Dr Nigel Duguid, respirologist, St John's, Newfoundland; Mrs Heather Alton, Manager, Community Care, Yukon Health and Social Services; Mrs Kim Riles, Director, Territorial Health Services, Department of Health and Social Services, Government of Northwest Territories; all personal communications) and, presumably, Nunavut (because no one at the Department of Health and Social Services in Iqaluit could be contacted). With the only exception of the document from Prince Edward Island, whose date of publication was not clearly specified, all terms of reference were published between 2007 and 2014. The extent of the documents ranged from a simple application form containing the eligibility criteria (eg, Prince Edward Island) to comprehensive guides detailing specific criteria to home oxygen therapy, terms of reimbursement and responsibilities of private
TABLE 1

Terms of reference for home oxygen therapy in Canada

\begin{tabular}{|c|c|c|}
\hline Province & Document / Policy title & $\begin{array}{l}\text { Last } \\
\text { revision date }\end{array}$ \\
\hline \multirow[t]{2}{*}{ British Columbia* } & Home Oxygen Program (HOP) Application & May 2012 \\
\hline & BC Home Oxygen Program Medical Eligibility & July 2012 \\
\hline Alberta & $\begin{array}{l}\text { Alberta aids to daily living. Respiratory Benefits } \\
\text { Program. Policy \& procedures manual }\end{array}$ & July 2013 \\
\hline Saskatchewan & $\begin{array}{l}\text { Saskatchewan aids to independent living } \\
\text { program (SAIL) - General policies } \\
\text { (Home oxygen program section) }\end{array}$ & $\begin{array}{l}\text { January } \\
2010\end{array}$ \\
\hline Manitoba & $\begin{array}{l}\text { Home oxygen concentrator program } \\
\text { (Policy No. HCS 207.7) }\end{array}$ & April 2009 \\
\hline Ontario & $\begin{array}{l}\text { Home oxygen therapy policy and } \\
\text { administration manual }\end{array}$ & April 2014 \\
\hline Quebec & $\begin{array}{l}\text { Program national d'oxygénothérapie } \\
\text { à domicile - Cadre de référence }\end{array}$ & June 2011 \\
\hline New Brunswick & $\begin{array}{l}\text { New Brunswick Extra-mural Program. } \\
\text { Provincial policy Manual. Chapter } 5 . \\
\text { Section 5.4.3 Home oxygen program - } \\
\text { Medical eligibility criteria }\end{array}$ & $\begin{array}{l}\text { September } \\
2008\end{array}$ \\
\hline Nova Scotia & $\begin{array}{l}\text { Home oxygen service - Procedures } \\
\text { \& guidelines }\end{array}$ & $\begin{array}{l}\text { September } \\
2007\end{array}$ \\
\hline $\begin{array}{l}\text { Prince Edward } \\
\text { Island }\end{array}$ & Home oxygen program application form & Not provided \\
\hline
\end{tabular}

${ }^{*}$ British Columbia is divided in five regional health authorities with their own assessment committee. They generally adhere to the same guidelines (Dr. Jeremy Road, respirologist, Vancouver, personal communication). Only the document from Vancouver Coastal Health was reviewed

equipment suppliers (eg, Alberta, Manitoba, Ontario, Quebec and Nova Scotia).

\section{Comparison among terms of reference}

Prescriber: In all nine provincial terms of reference, home oxygen can be prescribed by physicians. In two provinces (Manitoba and Nova Scotia), the indication of oxygen must be confirmed by physicians designated by regional or provincial authorities. In British Columbia, Saskatchewan and Ontario, nurse practitioners can also prescribe oxygen.

Eligibility criteria: Details regarding the criteria of funding for longterm, nocturnal and portable oxygen are provided in Table 2. In seven of the nine documents, general criteria apply to any health condition that may benefit from oxygen therapy, without distinction between COPD and other cardiorespiratory diagnoses. In Quebec, specific criteria exist for 10 cardiorespiratory different diagnoses including COPD. In Alberta, in addition to general eligibility criteria, special recommendations are provided for hypoventilation syndrome on longterm ventilatory support and for palliative cardiac patients.

All organizations have similar criteria for LTOT. However, slight differences exist in the thresholds of prescriptions and in the clinical criteria defining 'pulmonary hypertension' or 'cor pulmonale' when $\mathrm{PaO}_{2}$ is in the range of $56 \mathrm{mmHg}$ to $60 \mathrm{mmHg}$. The use of oxyhemoglobin saturation as a criterion for funding is inconsistent among provinces. Quebec, Nova Scotia and Prince Edward Island are the only three provinces that do not fund home oxygen on the basis of oxygen saturation alone. The notions of "clinical stability", "optimal therapy" and/or "reassessment" if the initial prescription of oxygen is made during the course of an exacerbation are included in the nine documents. All nine provinces fund nocturnal oxygen, all with different clinical criteria. Finally, funding for portable oxygen widely varies across provinces, whether the ambulatory equipment is offered to patients on LTOT or to those who have isolated exerciseinduced desaturation.

Palliative oxygen (Table 3): Even if palliative oxygen is provided in all nine provinces, the criteria for eligibility are heterogeneous. 
TABLE 2

General eligibility criteria for home oxygen

\begin{tabular}{|c|c|c|c|c|c|}
\hline Province & $\begin{array}{l}\text { Arterial blood gas } \\
\left(\mathrm{PaO}_{2}\right) \text { criteria }\end{array}$ & $\begin{array}{l}\text { Oxygen saturation } \\
\left(\mathrm{SpO}_{2}\right) \text { criteria }\end{array}$ & Nocturnal oxygen alone & $\begin{array}{l}\text { Portable oxygen for } \\
\text { patients on LTOT }\end{array}$ & $\begin{array}{l}\text { Portable oxygen for } \\
\text { exercise-induced desaturation }\end{array}$ \\
\hline British Columbia & $\begin{array}{l}\mathrm{PaO}_{2} \leq 55 \mathrm{mmHg} \text { or } \\
\leq 60 \mathrm{mmHg} \text { with evidence } \\
\text { of one of the following } \\
\text { condition: chronic heart } \\
\text { failure or pulmonary } \\
\text { hypertension }\end{array}$ & $\begin{array}{l}\mathrm{SpO}_{2}<88 \% \text { sustained } \\
\text { continuously for six } \\
\text { consecutive minutes } \\
\text { may be accepted }\end{array}$ & $\begin{array}{l}\text { In absence of comorbidities, } \\
\text { daytime desaturation must } \\
\text { be present at rest or with } \\
\text { ambulation for nocturnal } \\
\text { oxygen therapy to be } \\
\text { funded. } \mathrm{SpO}_{2} \text { must be } \\
<88 \% \text { for }>30 \% \text { of a } \\
\text { minimum } 4 \mathrm{~h} \text { nocturnal } \\
\text { oximetry study while } \\
\text { breathing room air }\end{array}$ & $\begin{array}{l}\text { Funded on evaluation } \\
\text { If client is unable to } \\
\text { walk } \geq 1 \mathrm{~min} \text {, ambulatory } \\
\text { oxygen will not be useful } \\
\text { and will not be funded }\end{array}$ & $\begin{array}{l}\text { Funded on evaluation } \\
\text { Hypoxemia on exercise is } \\
\text { defined as an exertional } \mathrm{SpO}_{2} \\
<88 \% \text { sustained continuously } \\
\text { for a minimum period of } \\
1 \text { min during the patient's } \\
\text { usual type of ambulation on } \\
\text { a level surface } \\
\text { Evaluation protocol and funding } \\
\text { criteria described }\end{array}$ \\
\hline Alberta & $\begin{array}{l}\mathrm{PaO}_{2} \leq 55 \mathrm{mmHg} \text { or } \\
<60 \mathrm{mmHg} \text {, with evi- } \\
\text { dence of cor pulmonale } \\
\text { (P pulmonale ECG pat- } \\
\text { tern, jugular venous dis- } \\
\text { tension, hepatomegaly, } \\
\text { peripheral edema), poly- } \\
\text { cythemia (hematocrit } \\
>55 \% \text { ) or pulmonary } \\
\text { hypertension (docu- } \\
\text { mented by pulmonary } \\
\text { artery pressure measure- }\end{array}$ & $\begin{array}{l}\mathrm{SpO}_{2} \leq 89 \% \text { for } 3 \text { consec- } \\
\text { utive minutes at rest } \\
\text { accepted as a criteria in } \\
\text { very specific circum- } \\
\text { stances (unsuccessful } \\
\text { arterial puncture, bed- } \\
\text { ridden patients). Prior } \\
\text { approval is required. } \\
\text { Maximum authorization } \\
\text { term is then } 3 \text { months, } \\
\text { with no further exten- } \\
\text { sion possible) }\end{array}$ & $\begin{array}{l}\text { At least one episode of } \\
\mathrm{SpO}_{2} \leq 83 \% \text { for } 5 \text { min on } \\
\text { level } 3 \text { sleep study; no evi- } \\
\text { dence of sleep-disordered } \\
\text { breathing; respiratory dis- } \\
\text { turbance index }<10) \text {. If } \\
\text { body mass index } \\
\geq 37 \mathrm{~kg} / \mathrm{m}^{2} \text {, a level } 1 \text { sleep } \\
\text { study must be done }\end{array}$ & $\begin{array}{l}\text { On occasion, suppliers may, } \\
\text { for convenience purposes, } \\
\text { provide a combination of } \\
\text { systems (eg, concentrator } \\
\text { and liquid oxygen; liquid } \\
\text { oxygen and cylinders). } \\
\text { Clients do not pay extra for } \\
\text { combination systems. } \\
\text { Suppliers do not charge } \\
\text { clients for combination } \\
\text { systems }\end{array}$ & $\begin{array}{l}\text { Funded on evaluation } \\
\text { Hypoxemia on exercise is } \\
\text { defined as an exertional } \mathrm{SpO}_{2} \\
<89 \% \text { continuously for at least } \\
\text { one continuous minute. } \\
\text { Evaluation protocol and fund- } \\
\text { ing criteria described }\end{array}$ \\
\hline
\end{tabular}

Saskatchewan or ultrasound)

$\mathrm{PaO}_{2} \leq 55 \mathrm{mmHg}$ or $\leq 59 \mathrm{mmHg}$ in the presence of cor pulmonale or polycythemia

$\mathrm{PaO}_{2} \leq 59 \mathrm{mmHg}$ on
room air

Saturation alone not accepted as a criteria in adults
Ontario
$\mathrm{PaO}_{2} \leq 55 \mathrm{mmHg}$ or $\mathrm{PaO}_{2}$ in the range of $56-60$ $\mathrm{mmHg}$ if one of the following is present: cor pulmonale, pulmonary hypertension or persistent erythrocytosis $\leq 87 \%$ for a minimum of two consecutive minutes or $\leq 90 \%$ in the presence of cor pulmonale or polycythemia

$\mathrm{SpO}_{2} \leq 87 \%$ for $>30 \%$ of the test time further evaluation

Nocturnal $\mathrm{SpO}_{2} \leq 85 \%$ for Not funded

a significant proportion of

sleep time (5\%); severe

episodes of desaturation

on 1 or 2 occasions per

night persisting for at least

5 min. Confirmed by either polysomnography or respiratory sleep study

$\mathrm{SpO}_{2} \leq 88 \%$ or $89-90 \%$ if one of the following is present: cor pulmonale, pulmonary hypertension or persistent erythrocytosis

Individuals with $\mathrm{PaO}_{2}$ $56-60 \mathrm{mmHg}\left(\mathrm{SpO}_{2}\right.$ $89-90 \%)$ may be candidates for funding if nocturnal hypoxemia is present (nocturnal hypoxemia not defined). The prescribed must submit a formal sleep study report to rule out sleep-disordered breathing that may be treatable by other means

Quebec $\quad \mathrm{PaO}_{2} \leq 55 \mathrm{mmHg} ; \mathrm{PaO}_{2}$ $\leq 59 \mathrm{mmHg}$ with peripheral edema, hematocrit $\geq 55 \%$, and/or $P$ pulmonale on ECG
Saturation alone not accepted for eligibility assessment
$\mathrm{SpO}_{2}<90 \%$ for $>30 \%$ of recording time, if clinical evidence of right heart failure or significant nocturnal arythmias are noted
Ten portable oxygen cylinders per month are provided with the oxygen concentrator, without

Funded on evaluation

The oxygen supply system is determined by the prescriber in consultation with the client and, if necessary, another regulated health professional. They should take into account the oxygen prescription, mobility needs and the cost effectiveness of the modality

Funded on clinical evaluation only; funded if the patient is able to go out of his/her home $\geq 4 \mathrm{~h} /$ week, has exercise-induced desaturation $(<85 \%$ on a 6 min walk test, and improves saturation $(>90 \%)$ on a repeat walk test performed with ambulatory oxygen
Funded upon evaluation

Hypoxemia on exercise is defined as an exertional $\mathrm{SpO}_{2} \leq 87 \%$ continuously for a minimum of $20 \mathrm{~s}$

Evaluation protocol and funding criteria described

Funded on evaluation

Hypoxemia on exercise is defined as an exertional $\mathrm{SpO}_{2}<90 \%$

Evaluation protocol and funding criteria described

Funded on evaluation

Hypoxemia on exercise is defined as an exertional $\mathrm{SpO}_{2} \leq 88 \%$

Evaluation protocol and funding criteria described

Not funded 
TABLE 2 - CONTINUED

General eligibility criteria for home oxygen

\begin{tabular}{|c|c|c|c|c|c|}
\hline Province & $\begin{array}{l}\text { Arterial blood gas } \\
\left(\mathrm{PaO}_{2}\right) \text { criteria }\end{array}$ & $\begin{array}{l}\text { Oxygen saturation } \\
\left(\mathrm{SpO}_{2}\right) \text { criteria }\end{array}$ & Nocturnal oxygen alone & $\begin{array}{l}\text { Portable oxygen for } \\
\text { patients on LTOT }\end{array}$ & $\begin{array}{l}\text { Portable oxygen for } \\
\text { exercise-induced desaturation }\end{array}$ \\
\hline New Brunswick & $\begin{array}{l}\mathrm{PaO}_{2}<55 \mathrm{mmHg} \text { or } \mathrm{PaO}_{2} \\
56-59 \mathrm{mmHg} \text { in addition } \\
\text { to evidence of cor } \\
\text { pulmonale, pulmonary } \\
\text { hypertension or second- } \\
\text { ary polycythemia } \\
\text { (hematocrit }>55 \% \text { ) }\end{array}$ & $\begin{array}{l}\mathrm{SpO}_{2}<89 \% \text { on room } \\
\text { air is accepted on } \\
\text { reassessment (com- } \\
\text { pleted within } 3 \text { months } \\
\text { of initial prescription) }\end{array}$ & $\begin{array}{l}\text { Polysomnography or } \\
\text { nocturnal oximetry must } \\
\text { confirm nocturnal desatu- } \\
\text { ration }{\left(\mathrm{SpO}_{2}<89 \% \text { on }\right.} \text { room air for at least } \\
5 \mathrm{~min})\end{array}$ & Not mentioned & $\begin{array}{l}\text { Exertional desaturation must } \\
\text { be confirmed by oximetry } \\
\text { studies on room air }\left(\mathrm{SpO}_{2}\right. \\
<89 \% \text { while performing usual } \\
\text { activities of daily living) }\end{array}$ \\
\hline Nova Scotia & $\begin{array}{l}\mathrm{PaO}_{2}<55 \mathrm{mmHg} \text { or in } \\
\text { the range of } 56-59 \\
\mathrm{mmHg} \text { with evidence of } \\
\text { cor pulmonale ( } \mathrm{P} \text { pulmo- } \\
\text { nale ECG pattern, jugu- } \\
\text { lar venous distension, } \\
\text { tender liver, peripheral } \\
\text { edema), or secondary } \\
\text { polycythemia (hematocrit } \\
>55 \% \text { ) }\end{array}$ & $\begin{array}{l}\mathrm{SpO}_{2} \text { level must be } \\
\leq 89 \%\end{array}$ & $\begin{array}{l}\text { Nocturnal desaturation con- } \\
\text { firmed by polysomnogra- } \\
\text { phy or nocturnal oximetry } \\
\text { tests (severe episodes of } \\
\text { arterial desaturation on } 1 \\
\text { or } 2 \text { occasions per night, } \\
\text { persisting } \geq 2 \text { min. This } \\
\text { type of individual spends } \\
\text { at least } 5 \% \text { of sleep time } \\
\text { with } \mathrm{SpO}_{2} \leq 85 \% \text { without } \\
\text { nocturnal oxygen therapy }\end{array}$ & $\begin{array}{l}\text { Portable oxygen cylinders } \\
\text { provided (to a maximum } \\
\text { of } 10 \text { cylinders per month) }\end{array}$ & $\begin{array}{l}\text { Funded on evaluation } \\
\text { Testing must demonstrate } \\
\text { desaturation to a } \mathrm{SpO}_{2} \\
\leq 80 \% \text {, regardless of } \\
\text { dyspnea or distance walked }\end{array}$ \\
\hline $\begin{array}{l}\text { Prince Edward } \\
\text { Island }\end{array}$ & $\begin{array}{l}\mathrm{PaO}_{2} \leq 55 \mathrm{mmHg} \text { or in the } \\
\text { range of } 56-59 \mathrm{mmHg} \\
\text { and evidence of cor pul- } \\
\text { monale, secondary poly- } \\
\text { cythemia (hematocrit } \\
>55 \% \text { ) or pulmonary } \\
\text { hypertension (confirmed } \\
\text { by evidence of pulmo- } \\
\text { nary artery pressure or } \\
\text { ultrasound indicating } \\
\text { elevated pulmonary } \\
\text { artery pressure) }\end{array}$ & $\begin{array}{l}\text { Saturation alone not } \\
\text { accepted for eligibility } \\
\text { assessment }\end{array}$ & $\begin{array}{l}\text { Nocturnal desaturation with } \\
\geq 5 \% \text { of sleep time with an } \\
\mathrm{SpO}_{2} \leq 85 \% \text { (confirmed by } \\
\text { polysomnography or a } \\
\text { sleep screening study } \\
\text { including continuous oxy- } \\
\text { gen saturation, heart rate } \\
\text { and direct measurement } \\
\text { of airflow. Obstructive } \\
\text { sleep apnea or periodic } \\
\text { breathing must be } \\
\text { excluded) }\end{array}$ & $\begin{array}{l}\text { Portable oxygen cylinders } \\
\text { provided (maximum: } \\
10 \text { cylinders per month) }\end{array}$ & Not funded \\
\hline
\end{tabular}

ECG Electrocardiogram; LTOT Long-term oxygen therapy; $\mathrm{PaO}_{2}$ Partial pressure of oxygen in arterial blood

Clinical indications, saturation criteria, period of funding and conditions of prescription renewal are all different. In Saskatchewan, coverage even includes portable oxygen cylinders.

Oxygen in current smokers (Table 4): Saskatchewan is the only province where no specific instruction is given when oxygen is prescribed to current smokers. In all eight other documents, restrictions to home oxygen therapy in smokers are more or less directive. Nova Scotia has the strictest restrictions.

Comparison with current Canadian recommendations and the international literature

In all nine documents, criteria for LTOT are based on the inclusion criteria of the NOTT trial (2), which are also supported by the CTS (9). Slight differences exist in the thresholds of prescriptions and the NOTT's clinical criteria defining pulmonary hypertension or cor pulmonale when $\mathrm{PaO}_{2}$ is in the range of $56 \mathrm{mmHg}$ to $60 \mathrm{mmHg}$. Although nocturnal and portable oxygen is funded everywhere, the CTS does not support the use of nocturnal oxygen in patients with isolated nocturnal desaturation, or the provision of ambulatory oxygen to patients with COPD.

In the nine terms of reference, oxygen for patients with interstitial disease is based on the same general eligibility criteria as those with COPD. In Cochrane reviews, the assumption that home oxygen therapy has a beneficial survival effect in patients with interstitial lung disease has not been demonstrated in the single randomized controlled trial identified by Crockett et al (10). Similarly, although palliative oxygen is funded everywhere, in cancer patients, it failed to demonstrate a beneficial effect over air breathing, although this conclusion was limited by the small volume of research studies available for inclusion (11).
Terms of reimbursement

Patients receive full funding in five provinces (British Columbia, Alberta, Manitoba, Saskatchewan and Quebec). In Ontario, full funding is provided for patients $\geq 65$ years of age; with few exceptions, $75 \%$ of the monthly rate is reimbursed for those $<65$ years of age. In New Brunswick, an amount of $\$ 100$ per month is reimbursed for the concentrator for individuals $\geq 65$ years of age; palliative oxygen is funded on a discretionary basis, and portable cylinders are provided for medical appointments only. In Nova Scotia, the funding program will pay approved vendors for the services provided in accordance with a detailed schedule (eg, $\$ 200$ per client per month for standard concentrator and related supplies, and $\$ 18$ per portable cylinder). Similarly, in Prince Edward Island, financial assistance is up to $50 \%$ of the approved home oxygen expenses, to a maximum of $\$ 200$ per month. Although not explicitly stated in most documents (with the exception of British Columbia, Ontario, Quebec and Nova Scotia), it was assumed that public funding for equipment and allied services was available only for those without any other source of benefits (such as private insurance plans, coverage from Veterans Affairs Canada or the Health Canada's Non-Insured Health Benefits Program (Table 5). The latter provides home oxygen to eligible registered First Nations and recognized Inuit, when it is not already provided through private insurance plans, provincial or territorial health and social programs, or other publicly funded programs.

In jurisdictions where no home oxygen program exists, oxygen may be obtained from different sources of funding. An example is in the Northwest Territories, where the Department of Health and Social Services has extended health benefit programs that provide full funding support for the purchase or rental of home oxygen, oxygen supplies and equipment. These programs require previous 
TABLE 3

Palliative oxygen

Province

Eligibility criteria

British Columbia Palliative diagnosis does not ensure home oxygen subsidy. Palliative clients must have hypoxemia according to the same criteria as for resting oxygen, ambulatory oxygen or nocturnal oxygen to be funded.

Alberta Approved if room air $\mathrm{SpO}_{2}<90 \%$ at rest during the daytime for at least 3 continuous minutes. "Palliative" must be written on the physician's prescription. The maximum authorization is for six months, and will only be extended for one six-month (maximum) period.

Saskatchewan The time frame for end-stage care may be measured in terms of days or weeks of active dying.

Eligibility is according to symptoms and performance status (not saturation).

Coverage includes a concentrator and 10 portable oxygen cylinders per month. Funding is for a maximum of four months; only a prescription is required to renew coverage.

Manitoba

Assessment for home oxygen therapy for a palliative care client conforms to the same medical eligibility criteria as those for resting hypoxemia.

Ontario

Funded for individuals who are at the end stage of a terminal illness (ie, life expectancy $<3$ months), are receiving end-of-life care and require home oxygen therapy. Funding is provided for a maximum period of 90 days.

Quebec Palliative oxygen may be considered if severe hypoxemia is present (saturation at rest $<88 \%$ ) in a patient with lung cancer or any other cancer with pulmonary involvement, if vital prognosis is estimated to be $<3$ months.

For non-neoplastic conditions, palliative oxygen may be considered if severe hypoxemia is present $\left(\mathrm{PaO}_{2}\right.$ $\leq 55 \mathrm{mmHg}$, or $<60 \mathrm{mmHg}$ in case of right heart failure).

New Brunswick For end-stage palliative patients, in whom terminal illness affects the respiratory system; $\mathrm{SpO}_{2}$ studies confirm oxygen desaturation with $\mathrm{SpO}_{2}<89 \%$ on room air.

Nova Scotia The home oxygen service does not provide funding assistance for home oxygen therapy when prescribed for psychological support of for breathlessness unsupported by evidence of hypoxemia.

Prince Edward Palliative care with a minimum of two oximetry results Island showing a \% saturation $<85 \%$ and requiring oxygen therapy for at least $18 \mathrm{~h}$ per day

$\mathrm{PaO}_{2}$ Partial pressure of oxygen in arterial blood; $\mathrm{SpO}_{2}$ Oxygen saturation

approval through Alberta Blue Cross, who administer the extended health benefit programs, and use the same guidelines as the NonInsured Health Benefits Program.

\section{DISCUSSION}

Our study uncovered heterogeneity in the criteria for eligibility for home oxygen programs and funding across Canada. More importantly, our findings indicate that the available evidence from the current literature does not necessarily translate into the terms of prescription and reimbursement of oxygen in several Canadian jurisdictions. Reimbursement for home oxygen may be quite different from one province to another. Our study also demonstrates that despite the CTS guidelines published in 2007, health care payers maintain their decision to fund, at least in COPD, nocturnal and ambulatory oxygen even if the evidence to support both interventions is lacking.

Of course, areas of agreement exist, with only minor differences in the thresholds of prescription for patients with daytime resting hypoxemia and in the definition of pulmonary hypertension and cor pulmonale" when $\mathrm{PaO}_{2}$ is in the range of $56 \mathrm{mmHg}$ to $59 \mathrm{mmHg}$. Also, all nine documents support the prescription of nocturnal oxygen;
TABLE 4

Home oxygen in current smokers

\begin{tabular}{|c|c|}
\hline Province & Recommandations \\
\hline British Columbia & $\begin{array}{l}\text { Smokers who do not comply with safety instructions will } \\
\text { be at risk of having oxygen funding discontinued imme- } \\
\text { diately and doctor notified. Home oxygen program will } \\
\text { not provide client with funding after the second reported } \\
\text { safety offence }\end{array}$ \\
\hline \multirow[t]{2}{*}{ Alberta } & $\begin{array}{l}\text { Supplier's respiratory therapist "advise clients not to } \\
\text { smoke when using oxygen" }\end{array}$ \\
\hline & $\begin{array}{l}\text { Home oxygen may be discontinued "if smoking habit } \\
\text { endangers the safety of self or others. This must be } \\
\text { documented on the file and the client's physician } \\
\text { informed" }\end{array}$ \\
\hline Saskatchewan & No specific mention about smoking \\
\hline Manitoba & $\begin{array}{l}\text { "The client and/or caregiver(s) agree(s) to adhere to safe } \\
\text { practices relative to delivery of oxygen therapy. There } \\
\text { should be no smoking, heat source or open flames within } \\
3 \text { meters (10 feet) of oxygen." }\end{array}$ \\
\hline Ontario & $\begin{array}{l}\text { "The applicant's medical condition must be stabilized } \\
\text { and treatment regimen optimized before home oxygen } \\
\text { therapy is considered. Optimum treatment includes } \\
\text { smoking cessation." }\end{array}$ \\
\hline \multirow[t]{2}{*}{ Quebec } & $\begin{array}{l}\text { Long-term oxygen therapy is not indicated in patients with } \\
\text { severe hypoxemia who are current smokers }\end{array}$ \\
\hline & $\begin{array}{l}\text { In patients who stopped smoking only recently, } 4 \text { weeks } \\
\text { of observation should be considered to ascertain smok- } \\
\text { ing cessation before oxygen therapy is started }\end{array}$ \\
\hline
\end{tabular}

New Brunswick The individual has an optimal medical program (defined as the medical treatment that stabilizes/reduces symptoms as much as possible and should include smoking cessation) in effect at the time of medical assessment for home oxygen therapy

Nova Scotia An applicant is not eligible if he or she is a smoker An applicant is not eligible if he or she refuses to sign a nonsmoking agreement or, in the case of pediatric clients, if the parent or guardian refuses to sign a nonsmoking agreement

Clients who are in receipt of home oxygen services and who are determined to be noncompliant with no smoking requirements, will have funding for the service discontinued for a minimum period of 3 months

Prince Edward Patients must certify that "there is no smoking allowed Island within my home or apartment"

however, with more important differences in the definition of nocturnal desaturation. Areas of disagreement are significantly more common when the indication or practice of oxygen therapy is not clearly evidence based. Examples include the use of oxyhemoglobin saturation as a criterion for funding and the restrictions to the prescription of oxygen to current smokers. The provision of portable cylinders to oxygen-dependent patients or for isolated exercise-induced desaturation and the conditions of reimbursement of oxygen in palliative care are other areas of controversy, although they correspond to issues that have been well addressed in randomized controlled trials and in meta-analyses that demonstrated the limitations of these interventions (12-17).

Even if it is expensive and, in several circumstances, of unproven efficacy, why is oxygen so easily reimbursed? One explanation may be that, in addition to being safe and readily available, the prescription of oxygen always makes sense: if oxygen desaturation exists, its correction should help. This reasoning was common before the introduction of 'evidence-based medicine', when the study and understanding of basic mechanisms of disease and pathophysiological principles were considered sufficient to guide clinical practice (18). However, numerous 
TABLE 5

General eligibility criteria for home oxygen in two federal funding programs

\begin{tabular}{|c|c|c|}
\hline & Veterans Affairs Canada* & Non-Insured Health Benefits ${ }^{\dagger}$ \\
\hline Prescriber & $\begin{array}{l}\text { A request for approval of LTOT must include reports from a } \\
\text { physician and a respiratory therapist who must include a } \\
\text { description of the equipment necessary to fulfill the pre- } \\
\text { scription and arterial blood gas data }\end{array}$ & Physicians \\
\hline Arterial blood gas $\left(\mathrm{PaO}_{2}\right)$ criteria & $\begin{array}{l}\mathrm{PaO}_{2} \leq 55 \mathrm{mmHg} \text {; or } \mathrm{PaO}_{2} \leq 60 \mathrm{mmHg} \text { with cor pulmonale, } \\
\text { secondary polycythemia or pulmonary hypertension }\end{array}$ & $\begin{array}{l}\mathrm{PaO}_{2} \leq 55 \mathrm{mmHg} \text {, or } \mathrm{PaO}_{2} 56-59 \mathrm{mmHg} \text { with cor pul- } \\
\text { monale, pulmonary hypertension and/or secondary } \\
\text { polycythemia }\end{array}$ \\
\hline
\end{tabular}

Oxygen saturation criteria

When a client lives >30 min from an arterial blood gas labora- Saturation alone not accepted for eligibility assessment tory setting or hospital where an arterial blood gas can be done, and travel to this centre is not feasible, an oximetry reading may be substituted using room air. The oximetry must indicate a level of saturation of $\leq 88 \%$ while awake and at rest for at least $5 \mathrm{~min}$ before oximetry is performed

Nocturnal oxygen alone

Nocturnal desaturations must be confirmed by a polysomnography or oximetry completed in a sleep laboratory, or by a sleep screening study. Nocturnal desaturation: $\geq 5 \%$ of sleep time with an oxygen saturation $\leq 85 \%$ without nocturnal oxygen therapy

Portable oxygen for patients on LTOT

Portable oxygen units (small cylinders of compressed oxygen or liquid oxygen) are approved for those clients who meet the criteria for LTOT who have led an active lifestyle prior and up to their need for oxygen and who require continuous oxygen to remain ambulatory outside the home or to maintain regular routines

Portable oxygen for exercise-induced Exercise-induced oxygen desaturation will not be recognized for LTOT except in exceptional circumstances. All of these cases would have to be individually medically judged by the Senior District Medical Officer with appropriate preauthorization

Palliative oxygen

Provided in exceptional cases for terminally ill clients who do not otherwise meet the approval criteria. In such cases the approval of long-term home oxygen should be reconsidered after 3 months

Saturation $<88 \%$ for $30 \%$ of the night, if daytime $\mathrm{PaO}_{2}$ 56-59 mmHg

\section{Funde} unded for a maximum of $8 \mathrm{~h}$ per day away from the principle residence

The Department will not be held responsible for any injury or damages resulting from the use of long-term home oxygen and smoking

Restriction for current smokers

*Veterans Affairs Canada. Oxygen Therapy and Respiratory Equipment (Program of choice 9). May 2012; ${ }^{\dagger}$ Health Canada. Provider guide for medical supplies and equipment (MS\&E) benefits. Non-Insured Health Benefits. April 2009. LTOT Long-term oxygen therapy; PaO 2 Partial pressure of oxygen in arterial blood

examples proved the contrary. For instance, although oxygen corrects oxygen desaturation and improves walked distance in patients with COPD and exercise-induced desaturation in laboratory testing (19), several trials have failed to demonstrate long-term benefits of this therapy $(14-17)$.

Terms of reference are not practice guidelines. Nevertheless, in a jurisdiction where medical insurance is universal, they can be assimilated to an insurance contract: they are powerful in delineating medical practice and prescriptions, and have an important financial impact. Funding of effective interventions depends on the maximum costeffectiveness ratio the payer is willing to accept. Funding of interventions that proved ineffective is a waste of money and resources for both the insurer and the policyholders. Funding of interventions of unknown or uncertain efficacy is debatable. This latter situation has at least one pernicious consequence: it is an obvious obstacle to further research. Such has been our own experience with the INOX trial in which recruitment has been stopped after an interim analysis in December 2014. We often faced the reluctance of patients and sometimes clinicians we had invited to participate as coinvestigators to engage into the trial, arguing that nocturnal oxygen therapy is available anyway.

Our study had limitations. It only investigated administrative documents. It did not provide insight into clinical practice and does not inform clinical outcomes. The rigour in the reinforcement of the terms of reference is also unknown. In this regard, the results of a study indicated that, in 2000, 96 of 237 patients (41\%) receiving domiciliary oxygen in the Ontario Ministry of Health Home Oxygen Program did not meet criteria for home oxygen (7). Whether the situation has since improved is unknown. We have no reason to believe that the situation was better elsewhere in the country when this study was conducted.

The results of our study call for action. Most terms of reference defining and governing eligibility to home oxygen equipment, allied services and reimbursement need in-depth revision. In addition to being evidence based, all terms of reference should also be regularly updated. Because health is under provincial jurisdiction in Canada, national terms of reference cannot be created. Closer monitoring of the prescriptions of home oxygen is also mandatory (8). Accordingly, provincial and national registries of patients on home oxygen should be created. Such registries would be useful in the conduct of clinical and epidemiological research, and to document variations in approaches to the prescription of LTOT. Finally, all efforts to generate evidence regarding the effect of oxygen therapy on survival and quality of life as well as its cost-effectiveness in a variety of conditions and indications must be encouraged. Such efforts are challenging because they require time, money and commitment from the investigators, the clinicians, the patients and their families to bring the clinical trials to their end. However, this investment is certainly worth it for the patients and those who will have to financially support home oxygen therapy. 


\section{REFERENCES}

1. BMRC. Long term domiciliary oxygen therapy in chronic hypoxic cor pulmonale complicating chronic bronchitis and emphysema. Report of the Medical Research Council Working Party. Lancet 1981;1:681-6.

2. Continuous or nocturnal oxygen therapy in hypoxemic chronic obstructive lung disease: A clinical trial. Nocturnal Oxygen Therapy Trial Group. Ann Intern Med 1980;93:391-8.

3. Bradley B, Branley HM, Egan JJ, et al. Interstitial lung disease guideline: The British Thoracic Society in collaboration with the Thoracic Society of Australia and New Zealand and the Irish Thoracic Society. Thorax 2008;63(Suppl 5):v1-58.

4. Badesch DB, Abman SH, Simonneau G, et al. Medical therapy for pulmonary arterial hypertension: Updated ACCP evidence-based clinical practice guidelines. Chest 2007;131:1917-28.

5. Yankaskas JR, Marshall BC, Sufian B, et al. Cystic fibrosis adult care: Consensus conference report. Chest 2004;125:1S-39S.

6. Chapman KR, Bourbeau J, Rance L. The burden of COPD in Canada: Results from the Confronting COPD survey. Respir Med 2003;97(Suppl C):S23-31.

7. Guyatt GH, McKim DA, Austin P, et al. Appropriateness of domiciliary oxygen delivery. Chest 2000;118:1303-8.

8. Wiener RS, Ouellette DR, Diamond E, et al. An official American Thoracic Society/American College of Chest Physicians policy statement: The Choosing Wisely top five list in adult pulmonary medicine. Chest 2014;145:1383-91.

9. O'Donnell DE, Aaron S, Bourbeau J, et al. Canadian Thoracic Society recommendations for management of chronic obstructive pulmonary disease - 2007 update. Can Respir J 2007;14(Suppl B):5B-32B.

10. Crockett AJ, Cranston JM, Antic N. Domiciliary oxygen for interstitial lung disease. Cochrane Database Syst Rev 2001; 2001/11/01:CD002883. <www.ncbi.nlm.nih.gov/entrez/query.fcgi?c $\mathrm{md}=$ Retrieve $\& \mathrm{db}=$ PubMed\&dopt $=$ Citation\&list_uids $=11687030>$ (Accessed November 2014).
11. Cranston JM, Crockett A, Currow D. Oxygen therapy for dyspnoea in adults. Cochrane Database Syst Rev 2008; 2008/07/23:CD004769. $<$ www.ncbi.nlm.nih.gov/entrez/query.fcgi?cmd=Retrieve\&db=PubMed $\&$ dopt $=$ Citation\&list_uids=18646110> (Accessed November 2014).

12. Lacasse Y, Lecours R, Pelletier C, et al. Randomised trial of ambulatory oxygen in oxygen-dependent COPD. Eur Respir J 2005;25:1032-8.

13. Uronis HE, Currow DC, McCrory DC, Samsa GP, Abernethy AP. Oxygen for relief of dyspnoea in mildly- or non-hypoxaemic patients with cancer: A systematic review and meta-analysis. Br J Cancer 2008;98:294-9.

14. Eaton T, Garrett JE, Young P, et al. Ambulatory oxygen improves quality of life of COPD patients: A randomised controlled study. Eur Respir J 2002;20:306-12.

15. McDonald CF, Blyth CM, Lazarus MD, et al. Exertional oxygen of limited benefit in patients with chronic obstructive pulmonary disease and mild hypoxemia. Am J Respir Crit Care Med 1995;152:1616-9.

16. Nonoyama ML, Brooks D, Guyatt GH, Goldstein RS. Effect of oxygen on health quality of life in patients with chronic obstructive pulmonary disease with transient exertional hypoxemia. Am J Respir Crit Care Med 2007;176:343-9.

17. Moore RP, Berlowitz DJ, Denehy L, et al. A randomised trial of domiciliary, ambulatory oxygen in patients with COPD and dyspnoea but without resting hypoxaemia. Thorax 2011;66:32-7.

18. Evidence Based Medicine Working Group. Evidence-based medicine. A new approach to teaching the practice of medicine. JAMA 1992;268:2420-5.

19. Bradley JM, Lasserson T, Elborn S, et al. A systematic review of randomized controlled trials examining the short-term benefit of ambulatory oxygen in COPD. Chest 2007;131:278-85. 


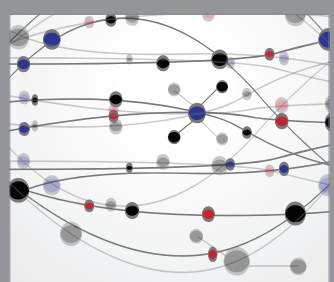

The Scientific World Journal
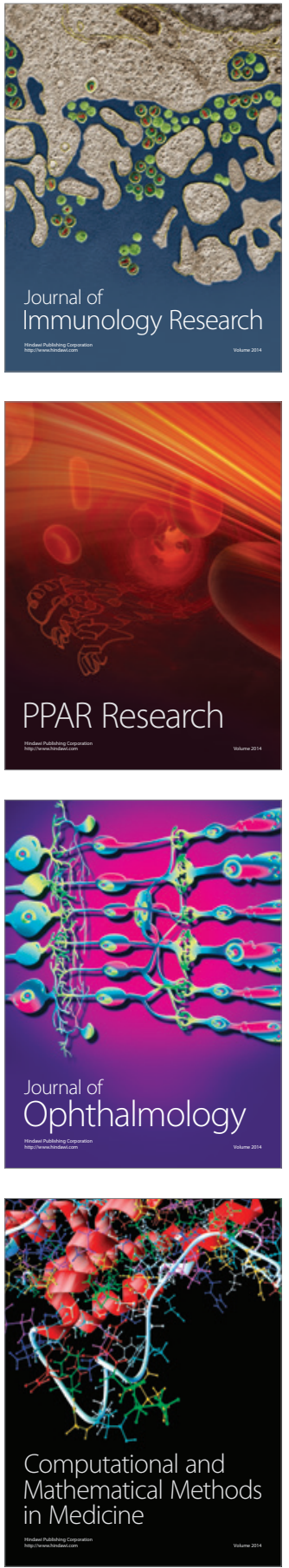

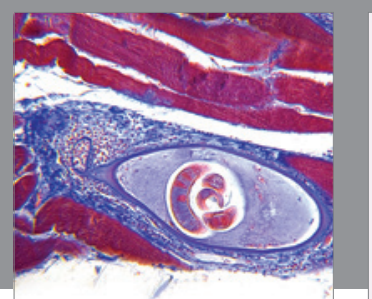

Gastroenterology Research and Practice

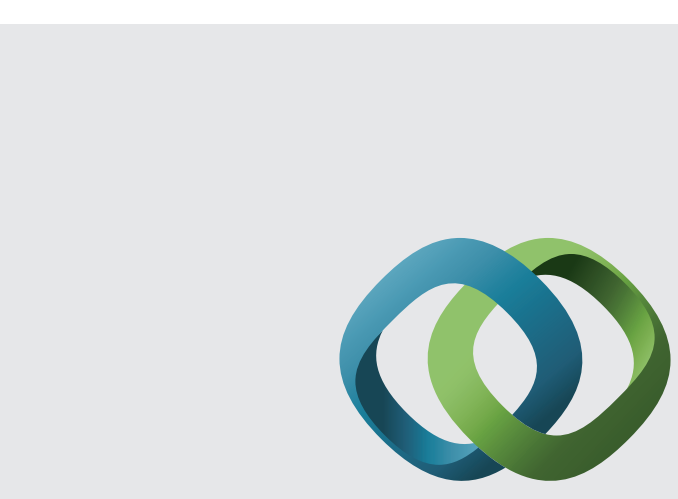

\section{Hindawi}

Submit your manuscripts at

http://www.hindawi.com
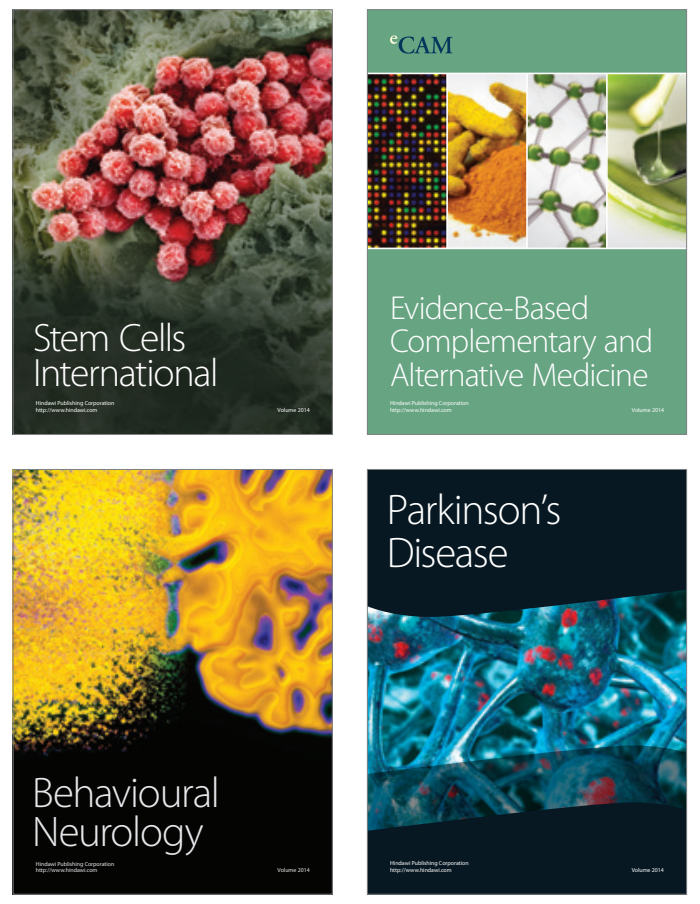
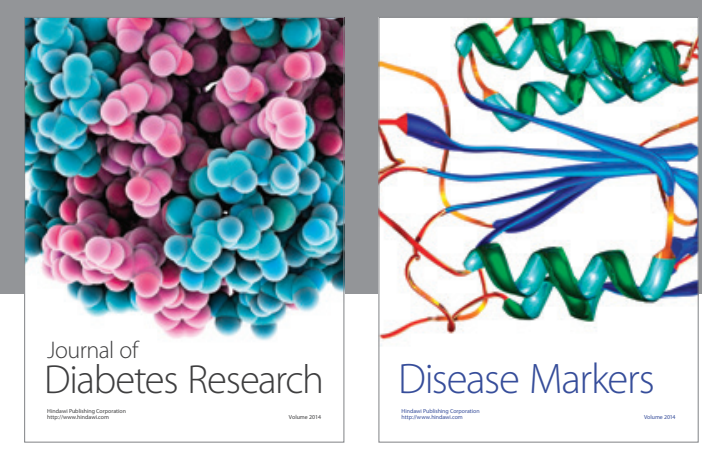

Disease Markers
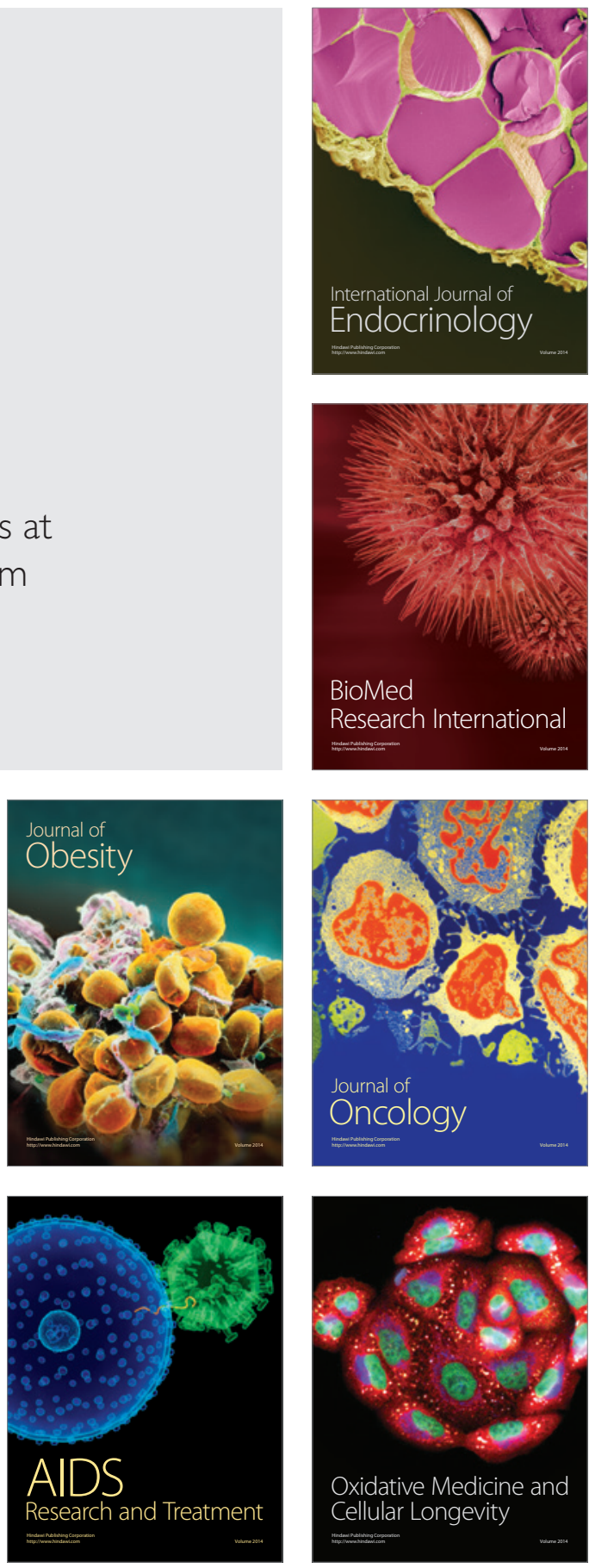